\title{
Requirement of the Hyaluronan Receptor RHAMM in Neurite Extension and Motility as Demonstrated in Primary Neurons and Neuronal Cell Lines
}

\author{
J. I. Nagy, ${ }^{1}$ J. Hacking, ${ }^{2}$ U. N. Frankenstein, ${ }^{1}$ and E. A. Turley ${ }^{2}$ \\ 'Department of Physiology and ${ }^{2}$ Manitoba Institute of Cell Biology, University of Manitoba, Winnipeg, Manitoba Canada \\ R3E OW3
}

The recently cloned and characterized hyaluronan (HA) receptor RHAMM (receptor for HA-mediated motility) has been shown to play a critical role in mechanisms underlying the motile capacity of a variety of peripheral cell types. Similarities in molecular processes that govern cell locomotion and growth cone migration prompted us to investigate whether RHAMM also contributes to neurite migration in vitro. In immunohistochemical studies of PC12 cells, NG108-15 cells and a neuroblastoma/spinal cord neuronal hybrid cell line (NSC-34 cells) as well as rat and human primary neurons, a punctiform RHAMM labeling pattern was detected in cell bodies, along processes, and at growth cones. By Western blot analysis, the cells lines expressed major RHAMM forms with apparent $\mathrm{MW}$ of 60,75 , and $116 \mathrm{kDa}$. Treatment of NG 108-15 cells with dibutyryl-cAMP led to a clear increase in immunolabeling for RHAMM and enhanced expression of the 60 and $75 \mathrm{kDa}$ forms. A polyclonal anti-RHAMM antibody that interferes with HA/RHAMM interaction significantly reduced neurite migration of each cell type examined, while another directed against a RHAMM repeat sequence thought to promote RHAMM receptor aggregation significantly stimulated neurite migration of NSC-34 and rat primary neurons. Different monoclonal anti-RHAMM antibodies had differential inhibitory actions on neurite movement. Low concentrations ( $\mathrm{ng} / \mathrm{ml}$ ) of a peptide corresponding to an HA binding domain within RHAMM inhibited neurite migration. These results are the first to implicate RHAMM in the mediation of neurite motility and migration and to point to the potential importance of HA in this process.

[Key words: hyaluronan receptors, RHAMM, neurite migration, PC12 cells, NG108-15 cells, extracellular matrix]

Molecules of the extracellular matrix (ECM) and their receptors regulate adhesive interactions and signaling events in a number of cellular processes including growth and motility. Studies fo-

Received Mar. 15, 1994; revised May 6, 1994; accepted June 16, 1994

Wc are grateful to Dr. A. Nath for providing cultures of human fetal ncurons and Dr. N. R. Cashman for providing us with the NSC-34 cell line. We thank P. Ochalski, B. Boguski, and C. Wang for expert technical assistance. This research was supported by a grant from the Rick Hansen Man in Motion Legacy Fund (RHMMLF) to J.I.N. and E.A.T., and by a grant from the Medical Research Council of Canada to J.I.N. A studentship to U.N.F. was provided by the RHMMLF and Summer Studentship support to J.H. was provided by the National Science and Engineering Council of Canada.

Correspondence should be addressed to Dr. J. I. Nagy, Department of Physiology, Faculty of Medicine, University of Manitoba, 770 Bannatyne Avenue, Winnipeg, Manitoba, Canada R3E 0W3.

Copyright (C) 1995 Society for Neuroscience $0270-6474 / 95 / 150241-12 \$ 05.00 / 0$ cused on, for example, fibronectin, laminin, vitronectin, collagen, and proteoglycans together with their receptors such as the integrins, high-affinity laminin/elastin receptor, and CD44 indicate that they are critical to tissue repair and embryogenesis. Numerous reports on the integrin and other classes of ECM receptors and their various ligands have also demonstrated important roles in neurite extension and neuronal cell migration (Bixby and Harris, 1991; Venstrom and Reichardt, 1993). Despite the presence of several hyaluronan (HA) binding proteins including hyaluronectin, versican/GHAP, and CD44 as well as high levels of the ECM component HA in the CNS (Werz et al., 1985; Delpech et al., 1989; Picker et al., 1989; Toole, 1990; Bignami et al., 1991, 1993a,b; Turley, 1991; Akiyama et al., 1993; Perides et al., 1993), little is known about HA function in neural tissue. Indeed, HA is generally considered to serve as a space-filling molecule that provides a watery environment enabling interactions between other cellular components (Margolis and Margolis, 1989). However, HA stimulates locomotion of several cell types in vitro (Toole, 1990; Laurent and Fraser, 1992; Turley, 1992) and may support the motility of neurons along morphogenetic migratory pathways (Bignami et al., 1991; Reichardt and Tomaselli, 1991). Since cell locomotion through tissue shares mechanistic commonalities with neurite migration through the ECM (Devoto, 1990), proteins that mediate the actions of HA on cell motility may also contribute to neurite migration and examination of $\mathrm{HA}$ receptors in neurites may clarify the role of $\mathrm{HA}$ in this process.

A logical candidate protein to examine is the protein RHAMM (receptor for hyaluronic acid-mediated motility). The amino acid sequence predicted from murine RHAMM cDNA (Hardwick et al., 1992) is unrelated to that of any other HA binding protein (Stamenkovic et al., 1989) and its increased expression in highly motile tumor cells, in fibroblasts, smooth muscle cells, and macrophages migrating in response to tissue injury suggests that it is fundamental to the process of cell locomotion (Turley et al., 1991; Savani et al., 1993). Moreover, RHAMM is found primarily at protruding lamellae of migrating cells (Turley and Torrance, 1985) and its expression is regulated by motilitypromoting factors including serum and cytokines such as TGF $\beta 1$ (Samuel et al., 1993). Further, antibodies as well as peptides mimicking HA-binding domain sequences of RHAMM block HA-induced cell locomotion (Turley et al., 1991; Hardwick et al., 1992; Samuel et al., 1993). Most dramatic is that overexpression of RHAMM gene products in transfected $10 \mathrm{~T} 1 / 2$ cells results in loss of contact inhibition and significantly increases cell locomotion without alterations of growth rates, which indicates that this gene is a critical regulator of cell contact and 
motile behavior (Yang et al., 1994). In view of the above, we have begun to investigate possible roles of this receptor in growth cone extension and motility. To explore a diversity of cell types in which RHAMM may be involved in neurite migration, RHAMM and the effects of anti-RHAMM reagents were examined in cultures of human and rat primary neurons as well as in several established neuronal cell lines.

\section{Materials and Methods}

Preparation of cultures. The three neuronal cell lines utilized in the present study were NSC-34 cells, NG108-15 cells, and PC1 2 cells. NSC34 cells (provided by Dr. N. R. Cashman, Montreal Neurological Institute, McGill University, Montreal) comprise various subclones of a mouse-mouse hybridoma cell line produced by fusion of motoneuronenriched primary spinal neurons with N18TG2 neuroblastoma cells. In addition to a multipolar neuron-like morphology, their neuronal properties include induction of myotube twitching when cocultured with mouse myotubes, expression of choline acetyltransferase and neurofilament proteins, and generation of action potentials (Cashman et al., 1992). In addition, they exhibit properties of adhesion to S-laminin similar to that of motoneurons (Hunter et al., 1991). NSC-34, PC12 and NG 108-15 cells were passaged at least once after thawing and maintained in $75 \mathrm{~cm}^{2}$ tissue culture flasks (Falcon) in DMEM1 [Dulbecco's modified Eagle's medium with $10 \%$ fetal bovine serum, $2.5 \mathrm{gm} / \mathrm{liter}$ sodium bicarbonate, $5 \mathrm{gm} /$ liter glucose, and $1 \%$ antibiotic-antimycotic solution (Sigma Chemical Co., St. Louis, MO] in a $5 \% \mathrm{CO}_{2} / 95 \%$ air incubator at $36^{\circ} \mathrm{C}$. Medium was changed twice weekly. Three to four days before cells were to be used for experiments, they were washed with HBSS and incubated for $2-3 \mathrm{~min}$ in $0.25 \%$ trypsin in HBSS at $36^{\circ} \mathrm{C}$. Following the addition of an equal volume of DMEM 1 , adherent cells were washed off the bottom of the flask by pipetting and the suspension was centrifuged at $100 \times g$ for $6 \mathrm{~min}$. After aspiration of the supernatant and resuspension in DMEM1, the cells were replated into Primaria $35 \mathrm{~mm}$ culture dishes at a density, determined by microscopic inspection of aliquots, which yielded cultures of approximately $10-25 \%$ confluence $24 \mathrm{hr}$ postplating. The $\mathrm{PCl} 2$ and NG108-15 cell cultures were each divided into two groups. One group of $\mathrm{PC} 12$ cell cultures were treated daily for $3 \mathrm{~d}$ with nerve growth factor (NGF) $(50 \mathrm{ng} / \mathrm{ml})$ and one group of NG108-15 cell cultures were treated daily for 2-3 d with dibutyryl-cyclic AMP (db-cAMP) (1 mM).

For preparation of fetal rat brainstem/spinal cord neurons, uteri were removed from timed-pregnant (E16-E18) Sprague-Dawley rats sacrificed by $\mathrm{CO}_{2}$ narcosis, and washed in two or three changes of HBSS, and 8-12 embryos were aseptically removed and rinsed in several changes of HBSS at room temperature. Brainstem/spinal cords dissected from embryos were placed into a $35 \mathrm{~mm}$ dish containing ice-cold HBSS, stripped of meninges, washed in fresh cold HBSS, and finely minced with a sterile razor blade. Tissue pieces were transferred to a $15 \mathrm{ml}$ centrifuge tube containing cold $\left(10^{\circ} \mathrm{C}\right) \mathrm{HBSS}$, allowed to settle, washed several times in room temperature HBSS, and then incubated for 20 min at $36^{\circ} \mathrm{C}$ in $5 \mathrm{ml}$ of $0.5 \%$ trypsin (Sigma Chemical Co.) in HBSS containing $50 \mathrm{KU} / \mathrm{ml}$ of DNase I type II-S (Sigma Chemical Co.) with gentle swirling every 4-5 min. The pieces were allowed to settle for 2$3 \mathrm{~min}, 3-4 \mathrm{ml}$ of solution was removed, and $2 \mathrm{ml}$ of MEMI-Eagle's Minimum Essential Medium (Sigma Chemical Co.) containing N2 supplements (GIBCO), 5\% fetal bovine serum (Hyclone), 5\% equine serum (Hyclone), $10 \mathrm{~mm}$ HEPES buffer, $6 \mathrm{gm} /$ /iter glucose, and $2.4 \mathrm{gm} /$ /iter sodium bicarbonate were added to neutralize the trypsin. The pieces were triturated 10-20 times with a flame-polished Pasteur pipette, the larger pieces were allowed to settle, and $1 \mathrm{ml}$ of supernatant was transferred to a $15 \mathrm{ml}$ centrifuge tube. After addition of $1 \mathrm{ml}$ of MEM 1 to the undissociated tissue pieces, the trituration procedure was repeated with pipettes of increasingly narrower bore until the tissue was largely dissociated. The cell suspension was brought to a volume of $15 \mathrm{ml}$ with MEM l, plated into $100 \mathrm{~mm}$ Primaria (Falcon) culture dishes, and kept in a $5 \% \mathrm{CO}_{2} / 95 \%$ air incubator at $36^{\circ} \mathrm{C}$ for $3-4 \mathrm{hr}$ to allow attachment of non-neuronal cells. The medium containing unattached cells was collected from the dishes, centrifuged at $100 \times \mathrm{g}$ for $6 \mathrm{~min}$ at $20^{\circ} \mathrm{C}$, the pellet was resuspended in $25 \mathrm{ml}$ of MEM1, diluted for appropriate seeding density, and $0.25 \mathrm{ml}$ aliquots were plated either in Primaria (Falcon) $35 \mathrm{~mm}$ tissue culture dishes for tracking of neurite migration or onto poly-D-lysine-coated $12 \mathrm{~mm}$ round Carolina Micro Coverglasses (Carolina Biological) for immunohistochemical staining. Cultures were maintained in a $5 \% \mathrm{CO}_{2} / 95 \%$ air incubator at $36^{\circ} \mathrm{C}$ for $2-3 \mathrm{~d}$ prior to use in experiments. Coverslips were coated by applying $0.2 \mathrm{ml}$ of a 50 $\mathrm{mg} / \mathrm{ml}$ solution of poly-D-lysine $(30-70 \mathrm{kDa}$; Sigma Chemical Co.) in sterile $0.1 \mathrm{~m}$ boric acid/ $\mathrm{NaOH}$ buffer ( $\mathrm{pH} \mathrm{8.4)}$ to each coverslip. They were then dried at $36^{\circ} \mathrm{C}$ for $1-2 \mathrm{hr}$, rinsed in calcium and magnesiumfree Hanks' Balanced Salt Solution (HBSS), and air dried.

Cultures of human fetal neurons were prepared from fetal brain tissue obtained from 12-16-week-old aborted fetuses. Brain tissues were obtained with approval from both Hospital and University ethics committees and with written consent from women undergoing elective termination of pregnancy. Tissues were placed into a sterile petri dish, healthy pieces of cortex were collected in $10 \mathrm{ml}$ of medium A consisting of RPMI- 1640 with $2.0 \mathrm{gm} / \mathrm{liter}$ sodium bicarbonate and $1 \%$ antibioticantimycotic solution (Sigma Chemical Co.), and blood vessels were stripped away. Tissues were then placed into a $50 \mathrm{ml}$ centrifuge tube containing $10 \mathrm{ml}$ of medium A, dissociated by trituration, and centrifuged at $200 \times g$ for $10 \mathrm{~min}$. The pellet was resuspended in $15 \mathrm{ml}$ of medium B consisting of Opti-MEM with $2 \mathrm{ml} /$ liter of $\mathrm{N} 2$ supplement (GIBCO), $2.4 \mathrm{gm} /$ liter sodium bicarbonate, $5 \%$ fetal bovine serum, and $1 \%$ antibiotic-antimycotic solution (Sigma Chemical Co.), and $5 \mathrm{ml}$ of the cell suspension was added to $75 \mathrm{~cm}^{2}$ flasks containing $20 \mathrm{ml}$ of medium B. The cells were grown in a $5 \% \mathrm{CO}_{2} / 95 \%$ air incubator at $36^{\circ} \mathrm{C}$ for at least 4 weeks. After the first 3 weeks in culture, the medium was changed and successive changes were then made weekly. When numerous well-developed neurons with extensive neurite growth and nonvacuolated cytoplasm were seen growing over a glial cell layer, the flasks were hand shaken and the medium containing dislodged neurons was pooled in $50 \mathrm{ml}$ centrifuge tubes and centrifuged at $200 \times \mathrm{g}$ for 10 min. The pellet was resuspended in 4-6 ml of medium $B$ and the suspension was plated into $35 \mathrm{~mm}$ Primaria (Falcon) tissue culture dishes as a concentration of $1 \mathrm{ml} / \mathrm{dish}$. The neurons were maintained in culture for 1-2 weeks until taken for immunohistochemistry or neurite tracking experiments.

Anti-RHAMM antibodies and RHAMM peptides. Two polyclonal and a varicty of monoclonal anti-RIIAMM antibodies were utilized in the present study. A polyclonal antibody (designated A-268) was prepared against a peptide corresponding to the amino acid sequence $268-288$ encoded in RHAMM cDNA (Hardwick et al., 1992). Another (designated A-124) was prepared against a peptide corresponding to the RHAMM amino acid sequence 124-144. As antibody A-268 has previously been shown to block fibroblast (Hardwick et al., 1992), macrophage (Savani et al., 1994a), and glial cell locomotion in vitro (Turley et al., 1994), while A-124 was found to stimulate locomotion of fibroblasts (Hall et al., 1993, 1994), both of these antibodies were tested for their effects on neurite migration. A total of 15 mouse monoclonal antibodies were prepared against native, purified RHAMM as previously described (Turley et al., 1991) and some of these that have been reported to influence the motility of a variety of peripheral cell types (Turlcy ct al., 1991, 1993; Pilarski et .al., 1993) were also examined here. The specificity of these polyclonal and monoclonal antibodies was demonstrated by their detection of RHAMM fusion protein and their recognition of corresponding RHAMM isoforms in cells lines as determined by Western blots (Savani et al., 1994a), and abolition of this reactivity after preadsorption with RHAMM fusion protein (Hardwick et al., 1992). Moreover, as shown by truncation of recombinant RHAMM protein (Savani et al., 1994a), the function-blocking polyclonal antiRHAMM antibody A-268 specifically recognizes the epitope on RHAMM corresponding to the synthetic peptide sequence against which it was raised. Further, antisera depleted of RHAMM antibodies by chromatography over a RHAMM fusion protein column no longer detected RHAMM on Western blots (not shown) or in fixed cultures. In addition, preimmune sera, control IgG, and scrambled peptide had no effect on ccll locomotion or neurite migration. We have also found that affinity-purified antibodies A-268 and A-124 have the same effects on the motility of fibroblasts as anti-RHAMM serum (unpublished observations). We have firmly established that our antibodies against peptides derived from murine cDNA sequences react with rat RHAMM (Savani et al., 1994a).

A peptide corresponding to the sequence of the first HA binding domain (amino acids 401-411) of two such domains in RHAMM (Yang et al., 1993) was synthesized at the Manitoba Institute of Cell Biology and HPLC purified to $99 \%$ homogeneity. This peptide blocks cell motility in vitro (Samuel et al., 1993) and in vivo (unpublished observations) and was tested at various concentrations for effects on neurite migration. As a control procedure, the effects of a scrambled version of this peptide was examined in some cultures. 
Immunohistochemistry. Randomly selected groups of 9-20 cultures of each of the cell types prepared as described above were taken for immunohistochemical staining at the same time that others were taken for analysis of neurite extension and motility. Cultures were fixed and stained essentially as previously described (Turley et al., 1994). Briefly, after aspirating the medium, cultures were rinsed for $1-2$ min with 0.1 M sodium phosphate buffer, pH 7.4 (PB), containing 0.9\% saline (PBS) and then fixed with $4 \%$ paraformaldehyde in $0.1 \mathrm{M}$ PB for $30 \mathrm{~min}$ at room temperature. Following a wash with PBS, cultures were incubated with various primary antibodies diluted in PBS containing $0.3 \%$ Triton X-100 (PBS-T). For immunolocalization of RHAMM, all cultures were incubated for $48 \mathrm{hr}$ at $4^{\circ} \mathrm{C}$ with a 1:300 dilution of a previously characterized rabbit polyclonal anti-RHAMM antibody (A-268) (Hardwick et al., 1992). Some rat primary neuronal cultures were simultaneously incubated with a 1:1,000 dilution of a monoclonal antibody against neurofilament protein (Sternberger Monoclonal Inc.) for colocalization analysis of this neuronal marker with RHAMM. Primary neuronal cultures were also taken for immunostaining with a 1:500 dilution of a rabbit anti-neuron-specific enolase (NSE) antibody (Chemicon) for assessment of the distribution and density of neurons in cultures prepared at different times. After the primary incubation, cultures were washed three times for 20 min with PBS-T and incubated for $1.5 \mathrm{hr}$ at room temperature with $\mathrm{Cy} 3$-conjugated sheep anti-rabbit IgG (diluted 1:250) (Sigma Chemical Co.) for detection of RHAMM. For labeling neurofilament protein, cultures were incubated with biotinylated horse antimouse IgG (diluted 1:100) (Vector), washed for 20 min once with PBS-T and twice with PBS, and further incubated with fluorescein isothiocyanate (FITC)-conjugated streptavidin (diluted 1:100 in PBS) (Amersham) for $1.5 \mathrm{hr}$ at room temperature. For detection of NSE, cultures were incubated with FITC-conjugated donkey anti-rabbit antibody (Vector) diluted 1:100. All cultures were then washed in PBS followed by a rinse in Tris- $\mathrm{HCl}$ buffer, coverslipped with antifade medium (Valnes and Brandtzaeg, 1985), and taken for microscopic examination. In control cultures, no labeling was seen after omission of primary antibodies. In double labeling studies, no $\mathrm{Cy} 3$ fluorescence was seen after omission of anti-RHAMM antibody and no FITC fluorescence was seen after omission of anti-neurofilament protein antibody, indicating the absence of primary and secondary antibody cross-reactions. In addition, labeling for RHAMM was greatly reduced in cultures incubated with antisera depleted of anti-RHAMM antibody by affinity chromatography on a column linked with RHAMM fusion protein followed by reconstitution of serum to original protein concentration (Hardwick et al., 1992). Fluorescence was examined on a Leitz Dialux 20 fluorescence microscope using a N2 Ploemopak filter cube (excitation $530-560 \mathrm{~nm}$; long pass $580 \mathrm{~nm}$ ) for Cy3 (excitation $\max 552 \mathrm{~nm}$; emission max 568-574) and a L3 Ploemopak filter cube (excitation $450-490 \mathrm{~nm}$; bandpass $500-540$ $\mathrm{nm}$ ) for viewing FITC. The N2/L3 combination gives negligible Cy3 fluorescence with L 3 illumination and, conversely, no FITC fluorescence with N2 illumination. For comparisons of RHAMM immunofluorcscence staining intensity with anti-RHAMM serum and antibody depleted serum, cultures were photographed at the same time on the same roll of film and prints were prepared under identical conditions. This was also the case for comparisons of staining in PC12 and NG108-15 cells cultured in the presence and absence of NGF in the case of the former and db-cAMP in the case of the latter.

Western blots. Due to the mixed cell types present in primary neuronal cultures and the resulting ambiguity in assigning particular forms of RHAMM to particular cells types, only NG108-15, PC12, and NSC34 cells were biochemically analyzed. Cells grown to about $50 \%$ confluence were harvested and lysed with RIPA buffer (Lipfert et al., 1992) containing the protease inhibitors PMSF $(5 \mathrm{mg} / \mathrm{ml})$, leupeptin $(1 \mathrm{mg}$ ) $\mathrm{ml})$, and aprotinin $(1 \mathrm{mg} / \mathrm{ml})$. Lysate protein concentrations were determined with a DC protcin assay kit (Bio- $\mathrm{Rad})$ and protcins werc separated on $10 \%$ SDS-polyacrylamide (PAGE) gels with $5-10 \mathrm{mg}$ of total protein loaded per lane. Nitrocellulose membranes containing transblotted proteins were blocked with defatted milk, incubated with anti-RHAMM antibody (A-268) (Hardwick et al, 1992) at a dilution of $1: 2000$, and developed by chemiluminescence using luminol and $\mathrm{H}_{2} \mathrm{O}_{2}$ (Amersham).

Neurite motility analysis. Neuronal cell lines and primary neurons were analyzed for neurite extension and motility $48-72 \mathrm{hr}$ after plating. Immediately prior to monitoring of cell processes, cultures received a medium change to $\alpha$-MEM medium buffered with sodium bicarbonate and 24 mM HEPES, equilibrated for $30 \mathrm{~min}$ and placed on a microscope stage heated to $37^{\circ} \mathrm{C}$. Video images were viewed with a Hamamatsu camera linked to a monitor, and randomly selected fields containing neurites were recorded utilizing an image analysis program (IMAGE I, Universal Imaging, NY). Images were obtained every 5-15 min over a 1-2 hr period, depending on rates of neurite migration assessed upon initial examination of each cell type. Rates of neurite migration were subsequently calculated by tracking changes in their location from frame to frame over the recorded period with the aid of the image analysis program precalibrated for spatial displacement measurements. Only individual neurites that grew unobstructed and remained free of contacts with other elements were chosen for movement analysis. At the various concentrations indicated in Results, either polyclonal or monoclonal anti-RHAMM antibodies, nonimmune $\mathrm{IgG}(1 \mathrm{mg} / \mathrm{ml})$, antisera (1:50 dilution) from which anti-RHAMM antibody had been removed by affinity chromatography on a RHAMM fusion protein affinity column, RHAMM-derived HA binding domain peptides, or corresponding scrambled peptides were added to cultures $15-30$ min prior to commencement of imaging. Data gathered from measurement of between 20 and 30 neurites per experiment for each cell type were analyzed for significance of the effects of reagents by Student's $t$ test. Values marked with asterisks in the figures were significant at a level of $p<0.01$ or greater.

\section{Results}

\section{Immunofluorescence}

The majority of NG108-15 cells maintained in the absence of $\mathrm{db}$-cAMP for $3 \mathrm{~d}$ after plating had large, flattened processes that often extended one-half or, very occasionally, one to two cell body lengths. Cells treated with db-cAMP exhibited both thin as well as thick bulbous processes with up to five cell bodylengths. In both untreated (Fig. $1 A$ ) and treated cells (Fig. $1 B-$ $D)$, RHAMM was localized throughout the cell bodies and was present in most processes. Intensity of cell labeling was clearly greater in cultures to which db-cAMP had been added. Labeling consisted of aggregates of either round or irregularly shaped puncta, and an increased concentration of these after db-cAMP treatment was particularly striking along swellings and at the ends of processes (Fig. 1D). A much finer granular labeling was also seen evenly distributed in the large, short, flat processes of db-cAMP-treated NG108-15 cells (not shown).

After $3 \mathrm{~d}$ in culture in the absence of NGF, PC1 2 cells tended to be clustered in small colonies, had a rounded appearance, and were almost entirely devoid of processes. These cells treated with NGF for 2 or $3 \mathrm{~d}$ had a more flattened, irregular morphology, and most, though not all, cells extended either short or long processes. In non-NGF-treated cells, weak to moderate punctate immunostaining for RHAMM was seen throughout the cell bodies and punctiform sites of more intense staining were seen discretely localized around the periphery of many cells (not shown). Treatment of PC12 cells with NGF led to a slight increase in cell body staining, moderate to intense staining of cell processes, particularly at their extremities, and a loss of the peripheral punctate staining seen in untreated cells (Fig. $1 F$ ). Immunolabeling of both NG108-15 (Fig. $1 E$ ) and PCl 2 (Fig. $1 G$ ) cells was greatly reduced in cultures processed with antiRHAMM serum eluted from a RHAMM fusion protein affinity column.

Shortly after plating, nearly all NSC-34 cells extended processes measuring about one cell body length, and numerous cells with multiple, short neurites were still evident $3 \mathrm{~d}$ after plating. Some cells had several thin, smooth, highly branched, and occasionally heavily varicose processes that measured up to 150 $\mathrm{mm}$ in length. Cell bodies and both short and long processes were consistently immunopositive for neurofilament protein (not shown). Immunolabeling for RHAMM in these cells had much the same appearance and distribution as seen in NG108-15 cells. Punctate immunoreactivity was localized in cell bodies and pro- 

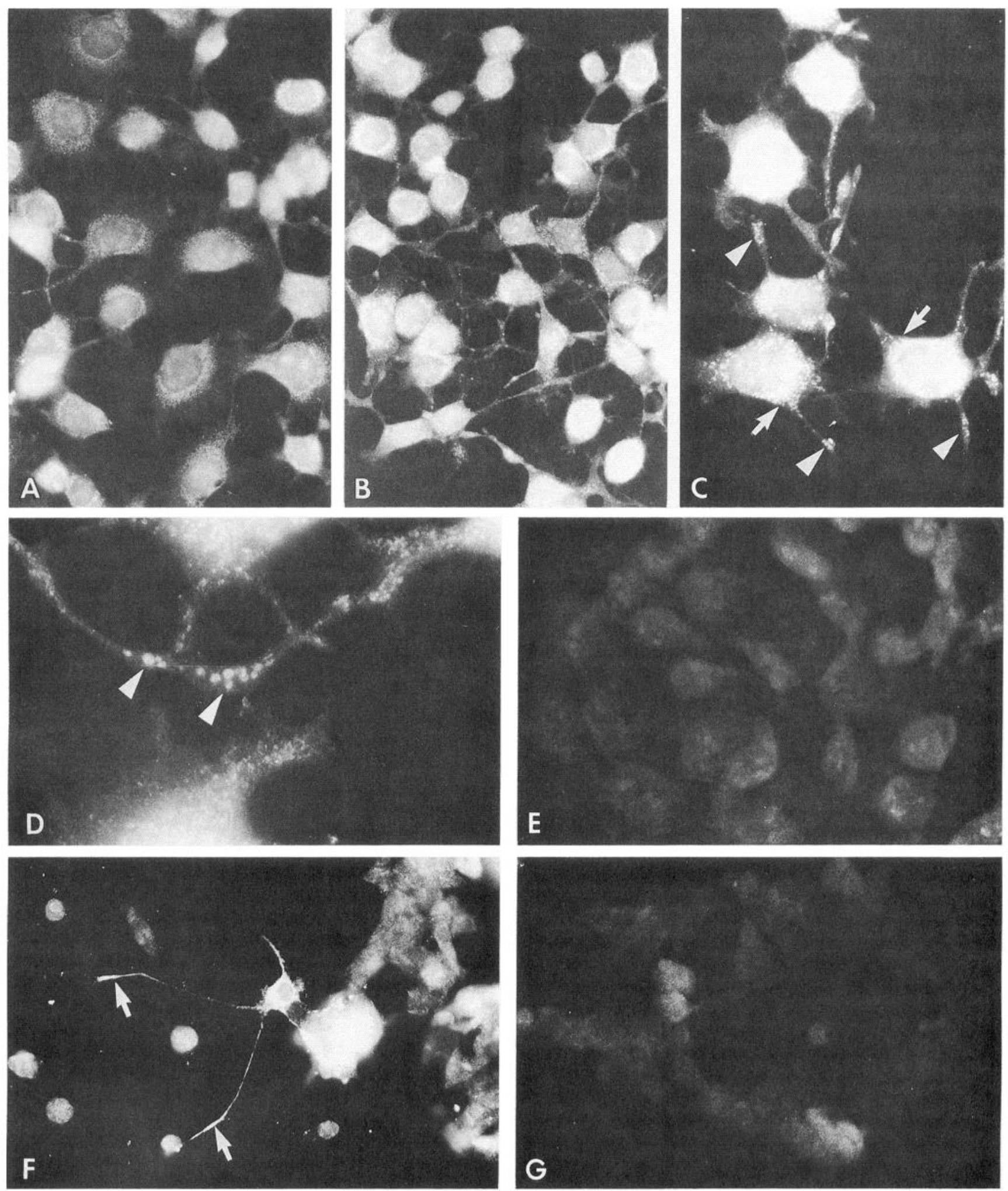

Figure 1. Immunofluorescence detection of RHAMM in NG108-15 and PC12 cells. NG108-15 cells were cultured in the absence $(A)$ or presence $(B-E)$ of db-cAMP, and PC1 2 cells $(F, G)$ in the presence of NGF. Both untreated $(A)$ and db-cAMP-treated $(B-D)$ NG108-15 cells contain RHAMM, but labeling intensity is greater in the latter. Punctiform aggregates of labeling for RHAMM are seen both in cell bodies ( $C$, arrows) as well as along and at the ends of processes ( $C$ and $D$, arrowheads). In PC1 2 cells, staining is seen in cell bodies and is distributed along processes $(F$, arrows) that form after NGF treatment. Little labeling is seen with immune serum depleted of anti-RHAMM antibody affinity chromatography $(E$, $G$ ). Magnification: $A, B$, and $E, 225 \times ; C, 380 \times ; D, 820 \times ; F$ and $G, 200 \times$. 

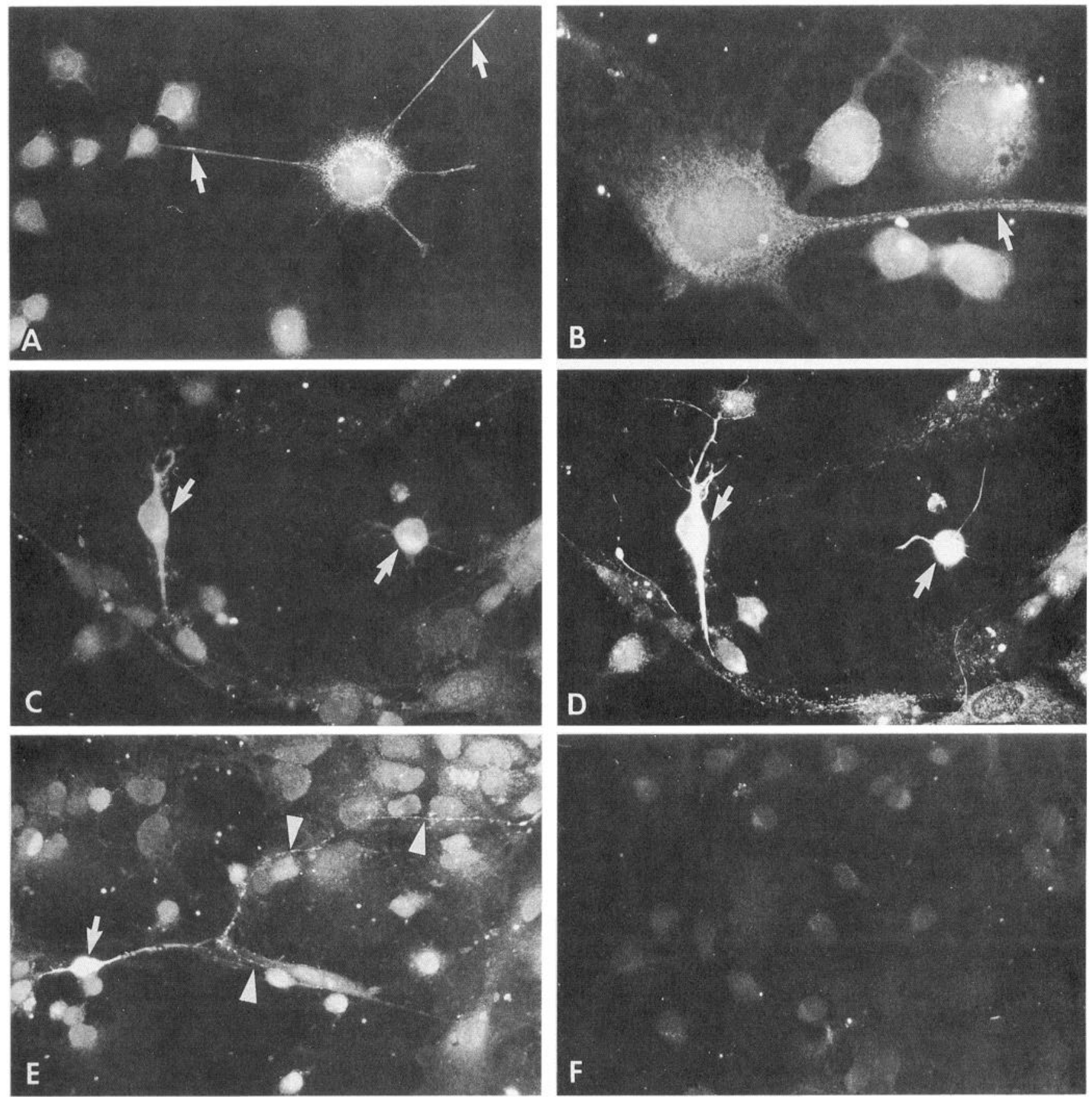

Figure 2. Immunofluorescence detection of RHAMM in NSC-34 cells ( $A$ and $B)$ and in primary neurons $(C-F)$ prepared from E18 rat brainstem/ spinal cord. In NSC-34 cells, patchy or punctate immunolabeling for RHAMM is seen throughout cell bodies as well as in long processes ( $A$ and $B$, arrows). In primary neurons double-labeled for RHAMM and neurofilament protein, photomicrographs of the same field $(C$ and $D)$ show that RHAMM-positive cells $(C$, arrows) are also labeled for neurofilament protein $(D$, arrows). Thin processes emerging from RHAMM-positive neurons $(E$, arrow $)$ and extending over long distances over the surface of astrocytes exhibit intermittent labeling for RHAMM (E, arrowheads). No labeling is seen with anti-RHAMM serum depleted of antibody $(F)$. Magnification: $A$ and $E, 170 \times ; B$ and $F, 260 ; C$ and $D, 330 \times ; E, 230 \times$.

cesses, tended to be more concentrated in long compared with short processes (Fig. $2 A, B$ ) and was more abundant at swellings along varicose processes than along intervaricose segments (not shown). Labeling was eliminated in cells processed with serum depleted of anti-RHAMM antibody (not shown).

Primary neurons prepared from embryonic rat brainstem/ spinal cord tissue had a healthy appearance by $3 \mathrm{~d}$ after plating as judged by their density, phase brightness, and elaboration of numerous processes over either a bed layer of astrocytes or on exposed plastic or poly-D-lysine-coated substratum. Cells with this neuronal morphology were found to be immunopositive for NSE (not shown). Neurons exhibited a wide range of staining intensity for RHAMM (Fig. $2 B, C$ ) in view of which it was difficult to discern whether all primary neurons expressed this protein. However, in cultures double stained for both RHAMM (Fig. $2 C$ ) and neurofilament protein (Fig. $2 D$ ), cells stained for 

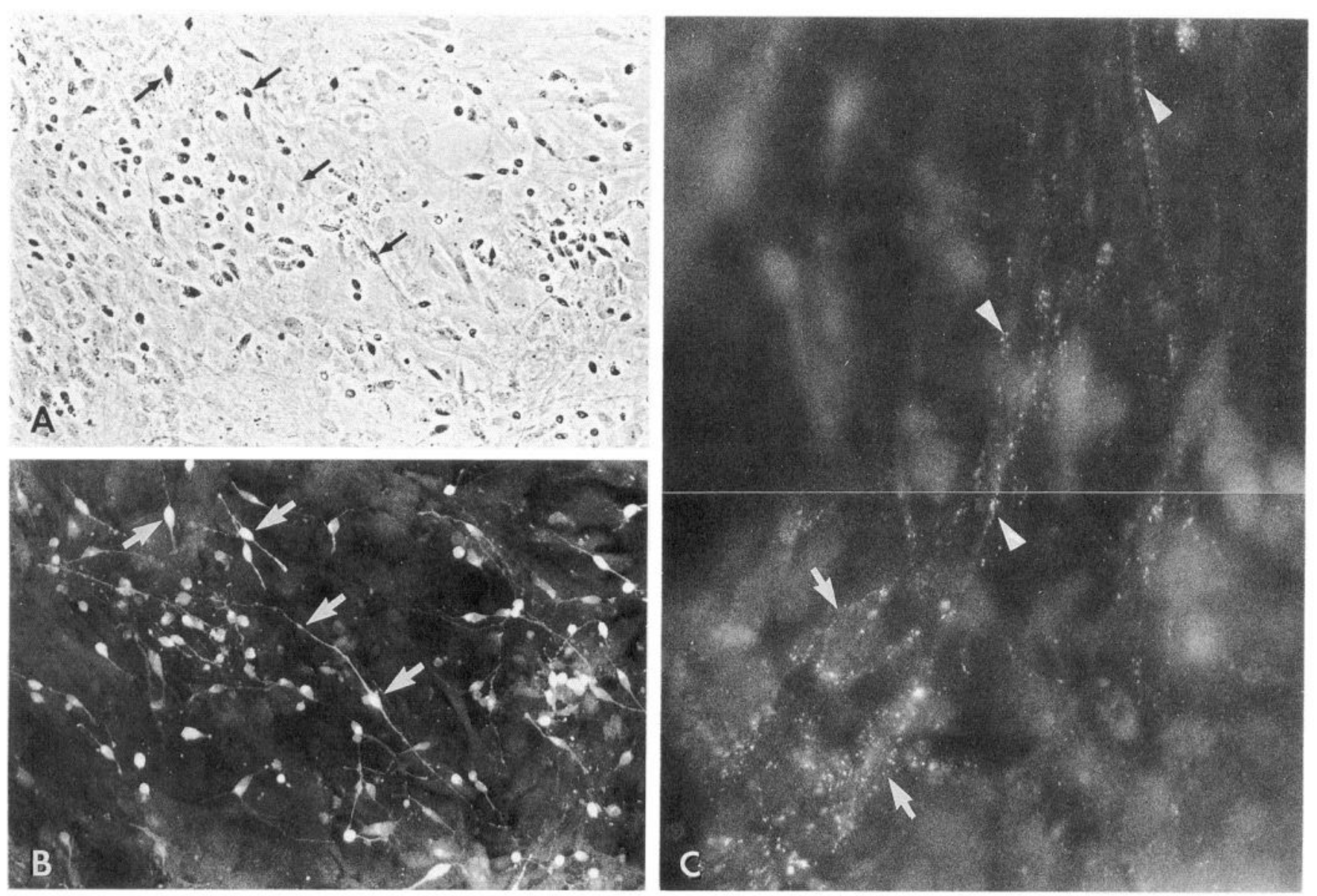

Figure 3. Immunofluorescence detection of RHAMM in primary neurons prepared from human fetal brain. Phase contrast $(A)$ and immunofluorescence labeling for NSE $(B)$ in the same field illustrate that neurons and neuronal processes $(A$, arrows) growing on a bed of astrocytes are NSE positive (corresponding arrows in $B$ ). Photomontage at a focal plane above the bed layer of astrocytes shows punctate labeling for RHAMM in neuronal cell bodies $(C$, arrows) and their processes $(C$, arrowheads). Magnification: $A$ and $B, 130 \times ; C, 520 \times$.

the latter were consistently found to be immunopositive for RHAMM. RHAMM immunoreactivity was concentrated in cell bodies as well as in short neurites and relatively thick initial processes, at swellings along beaded processes and intermittently along thin processes that extended considerable distances from neuronal cell bodies (Fig. $2 E$ ). Due to their presence on the surface of astrocytes, it was difficult to ascertain fine features of RHAMM labeling in neurons. The underlying astrocytes were also immunopositive for RHAMM, and these displayed a labeling pattern similar to that previously reported (Turley et al., 1994). All labeling was reduced in cultures processed with control serum (Fig. $2 F$ ).

Human primary neurons, as shown by phase contrast optics (Fig. $3 A$ ) and by NSE immunolabeling in the same field (Fig. $3 B$ ), had much the same appearance as rat primary neurons. Labeling for RHAMM in these neurons was seldom distributed throughout the perikaryal compartment, but rather was sparse and finely punctate (Fig. $3 C$ ). Similar labeling of slightly lower intensity was evident along neuronal processes. Throughout of the plane of focus in Figure $3 C$, many but not all of the underlying non-neuronal cells displayed intense punctate staining for RHAMM. Due to a limited supply of these cultures and the demonstrated specificity of the anti-RHAMM antibody, staining with control anti-RHAMM serum was not conducted.

\section{Western blots}

Results of Western blot analyses of total protein lysates obtained from NG108-15 cells cultured for $3 \mathrm{~d}$ in the presence and absence of db-cAMP are shown in Figure 4. Nitrocellulose membranes containing transblotted proteins from untreated cells (Fig. $4 A$, lane 1) and cells treated with db-cAMP for $1 \mathrm{~d}$ (Fig. $4 A$, lane 2 ) and $2 \mathrm{~d}$ (Fig. $4 A$, lane 3 ) revealed three corresponding immunoreactive bands when probed with anti-RHAMM antibody A-268. Untreated cells produced a major RHAMM isoform of $75 \mathrm{kDa}$ as well as forms having estimated molecular weights of 116 and $60 \mathrm{kDa}$. A very faint band was also detected at $48 \mathrm{kDa}$. In lysates of cells treated with db-cAMP, the levels of both the 75 and $60 \mathrm{kDa}$ isoforms were elevated at both the posttreatment times examined. In lysates of cultured NSC-34 cells, Western blots probed with anti-RHAMM antibody A-268 revealed two major protein forms of RHAMM migrating with apparent MW of 116 and $75 \mathrm{kDa}$ (Fig. $4 B$ ). Although run on a separate gel, these forms likely correspond to the 116 and 75 kDa RHAMM proteins detected in NG108-15 cells and, as in the case of the latter, the $75 \mathrm{kDa}$ form was slightly more abundant in the NSC-34 cells. PC12 cells expressed the same forms of RHAMM seen in NSC-34 cells, except that the $75 \mathrm{kDa}$ form was present in relatively greater abundance (Fig. $4 C$ ). There 


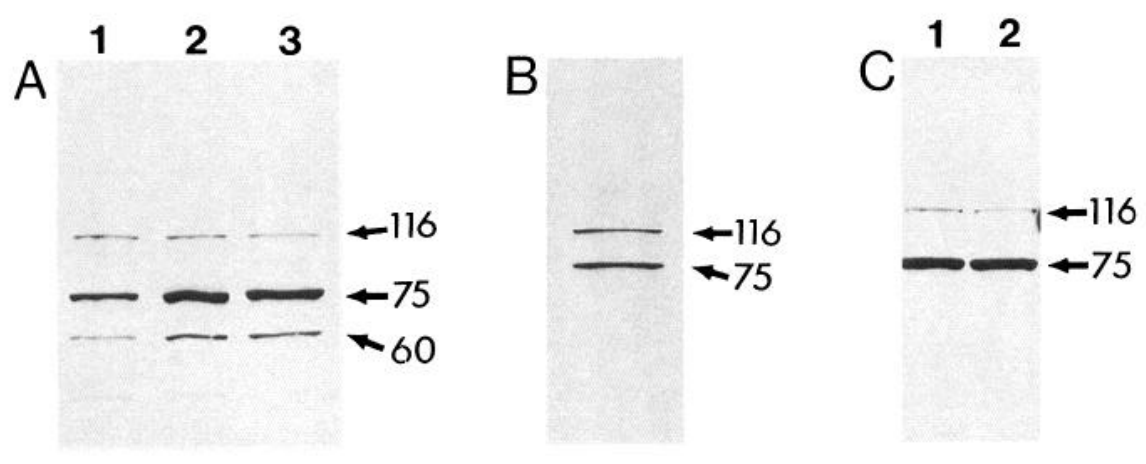

Figure 4. Western blot analysis of RHAMM in NG108-15 and NSC-34 cells. Equal quantities of lysate proteins from NG108-15 (A), NSC-34 $(B)$, and PC12 $(C)$ cells were separated on polyacrylamide gels, transblotted, and probed with A-268 anti-RHAMM antibody. All three cell types produced RHAMM proteins of 116 and $75 \mathrm{kDa}$. NG108-15 cells produced an additional $60 \mathrm{kDa}$ protein. Compared with NG108-15 cells cultured in the absence of db-cAMP $(A$, lane 1$)$, enhanced expression of the 75 and $60 \mathrm{kDa}$ RHAMM proteins was seen in these cells cultured in the presence of db-cAMP for $1 \mathrm{~d}(A$, lane 2$)$ and $2 \mathrm{~d}(A$, lane 3$)$. No differences in RHAMM levels were detected in NGF-treated $(C$, lane 1$)$ and untreated $(C$, lane 2) cultures of $\mathrm{PC} 12$ cells.

appeared to be no differences in the levels of RHAMM in PC12 cells that were treated with NGF (Fig. 4C, lane 1) compared with those that were not treated (Fig. $4 C$, lane 2).

\section{Neurite extension and motility}

All three cell lines as well as primary rat and human fetal neurons were taken for examination of the effect of a polyclonal antiRHAMM antibody on neurite extension and motility. This antibody at a dilution of 1:50, which was determined to be an optimal concentration for achieving motility inhibition of peripheral cell types in vitro, significantly reduced neurite migration of NG108-15 cells by threefold (Fig. $5 A$ ), PC12 cells by twofold (Fig. 5B), NSC-34 cells by fourfold (Fig. $5 C$ ), rat primary neurons by fourfold (Fig. $5 D$ ), and human fetal neurons by twofold (Fig. $5 E$ ). Analyses of the time-lapse images of control cultures receiving either no additions or treatments with preimmune serum, between which no significant differences in neurite migration were observed, indicated that net neurite extension was a dynamic process involving sequential periods of both extension and retraction. This was especially true of short neurites with one to two cell body lengths emanating from NSC34 cells that, although exhibiting a similar net rate of overall elongation as the other cells examined, were, in fact, difficult to track due to their rapid extension from and equally rapid withdrawal into the cell body (not shown). Addition of the antibodies inhibited both extension and retraction so that processes appeared to be frozen in position. In these studies, although no attempt was made to determine the time course or rapidity of action of the reagents added to cultures, it appeared that their full effect was exerted within the 15-30 min preincubation before imaging was begun.

Neurite migration of NSC-34 cells and rat primary neurons were also assessed for the effects of monoclonal anti-RHAMM antibodies. With dilutions of all monoclonal antibodies of 1:50, it was found here that monoclonal antibody $3 \mathrm{~T} 3-3$ significantly blocked $(p<0.0001)$ the migration of NSC-34 cell neurites by twofold (Fig. 6A), while neither antibody 3T3-7 nor 3T3-8 obtained from different hybridomas had any effect on the neurites of these cells. In contrast, antibody 3T3-7 effectively and significantly blocked neurite extension of rat primary neurons by eightfold (Fig. $6 \mathrm{~B}$ ), but other monoclonal antibodies (data not shown), as exemplified by antibody 3 T3-6, had no such inhib- itory actions. Since all of the monoclonal antibodies used here were of the IgG1 isotype, the nonblocking monoclonal antibodies served as isotype controls in these studies. That the differential responses of neurites to these antibodies were not simply due to differences in antibody titers was indicated by ELISA assays of IgG1, which showed similar titers for each of the ascites used. Moreover, antibodies exhibiting an inhibitory action on neurites of NSC-34 cells were found to be devoid of actions on those of rat primary neurons (Fig. 6) and, conversely, some that lacked effects on neurites of NSC-34 cells inhibited neurite movement of rat primary neurons (data not shown).

To determine further whether other antibody reagents against RHAMM have the same actions on neurite migration as they do on the locomotion of various peripheral cell types in vitro, we examined the effects of a polyclonal antibody (designated A-124) generated against a peptide corresponding to a region in the RHAMM sequence (amino acids 124-144) that is repeated five times within the molecule. This anti-repeat sequence antibody significantly stimulated neurite migration of both NSC34 cells by twofold $(p<0.0001)$ at a dilution of 1:1000 (Fig. $7 A$ ) and rat primary neurons by two- to threefold at dilutions of $1: 1000$ and $1: 5000$ (Fig. $7 B$ ). The stimulatory action was lost at higher dilutions and, notably, was absent at lower dilutions where, instead, a nonsignificant inhibition of $40 \%$ compared with control was observed. No differences in neurite dynamics were observed between culture receiving no additions and those treated with A 124 preimmune serum.

To assess further the potential contribution of RHAMM/HA interactions to neurite migration, we determined the effect of a peptide with an amino acid sequence corresponding to one of the two HA binding domains within RHAMM. Addition of RHAMM peptide to cultures at concentrations of $25 \mathrm{ng} / \mathrm{ml}$ or greater significantly $(p<0.001)$ inhibited neurite migration of NSC-34 cells (Fig. 8A). Lower concentrations had no significant effect, while concentrations of 50 and $100 \mathrm{ng} / \mathrm{ml}$ abolished their movement nearly entirely. In contrast, rat primary neurons appeared to be much more sensitive to the inhibitory effects of the RHAMM peptide such that neurite migration was significantly $(p<0.01)$ reduced by twofold at concentrations as low as $1.5 \mathrm{ng} / \mathrm{ml}$ (Fig. $8 B$ ). However, the maximum degree of inhibition achieved with doses of peptide as high as $50 \mathrm{ng} / \mathrm{ml}$ did not reach that seen in the case of NSC-34 neurites. As controls 

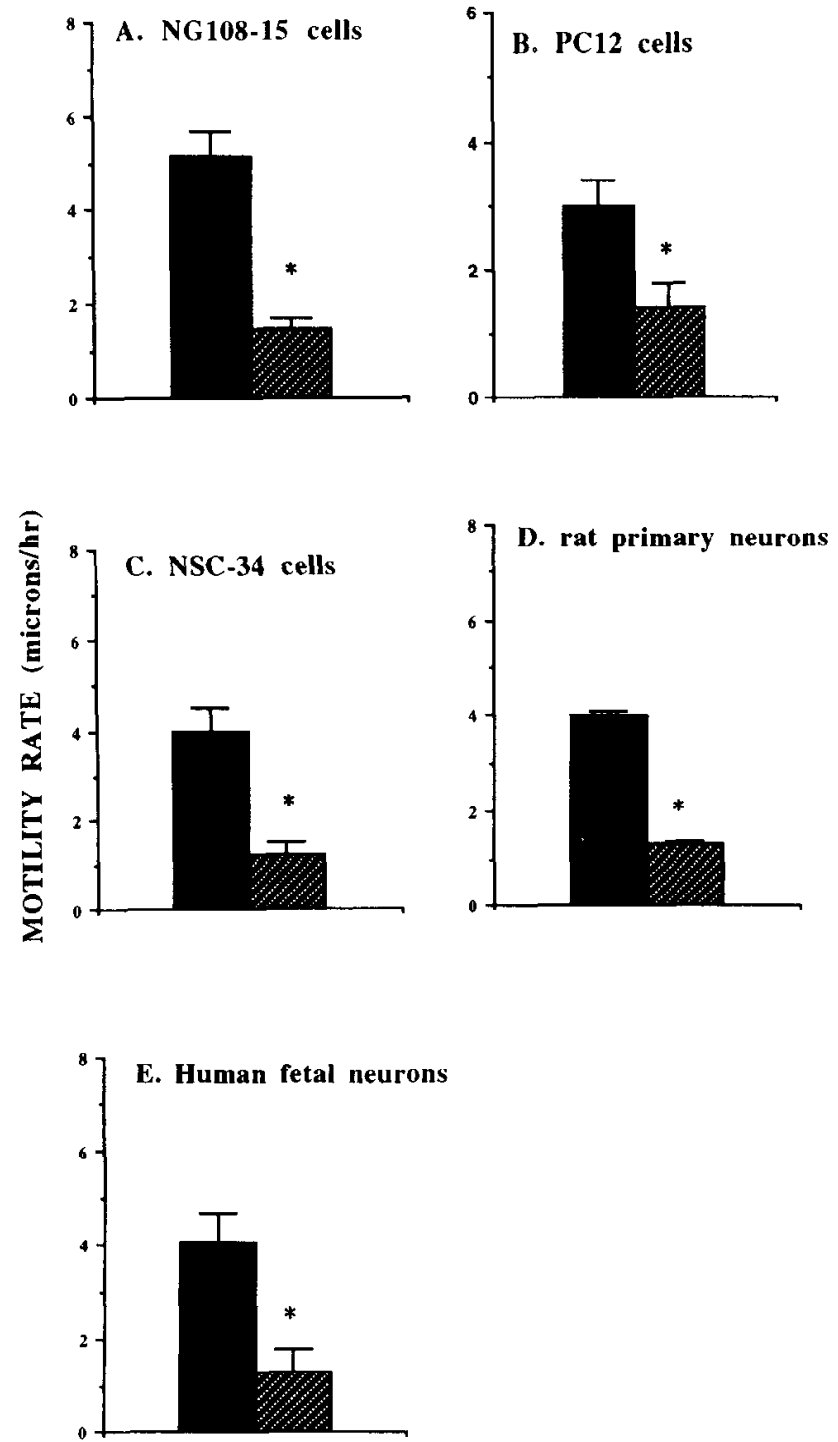

Figure 5. Polyclonal anti-RHAMM antibody inhibition of neurite migration in cultures of neuronal cell lines and primary neurons. Culture preparations indicated in $A-E$ were treated with either control preimmune serum (solid hars) or polyclonal anti-RHAMM (A-268) antibody (hatched bars) and neurites were tracked for $1-2 \mathrm{hr}$ by image analysis. Neurite migration was significantly inhibited in antibody-treated compared with control cultures $(*,+<0.01)$. Error bars represents SD of between 20 and 30 neurites tracked.

in these experiments, scrambled peptide added to NSC-34 and rat primary neuronal cultures at a concentration of $50 \mathrm{ng} / \mathrm{ml}$ was found to be devoid of actions on neurites when compared with cultures that received additions of vehicle solution alone.

\section{Discussion}

This report is the first documentation of the HA binding protein RHAMM in neurons and its involvement in neurite extension. We have shown that RHAMM is concentrated at the tips as well as along neurites, that anti-RHAMM antibodies exhibit domain-specific inhibition and stimulation of neurite migration in neuronal cultures, that a peptide mimicking an HA-binding domain in RHAMM inhibits neurite migration, and that RHAMM expression is increased in NG108-15 cells induced to sprout neurites in the presence of db-cAMP. These obser-

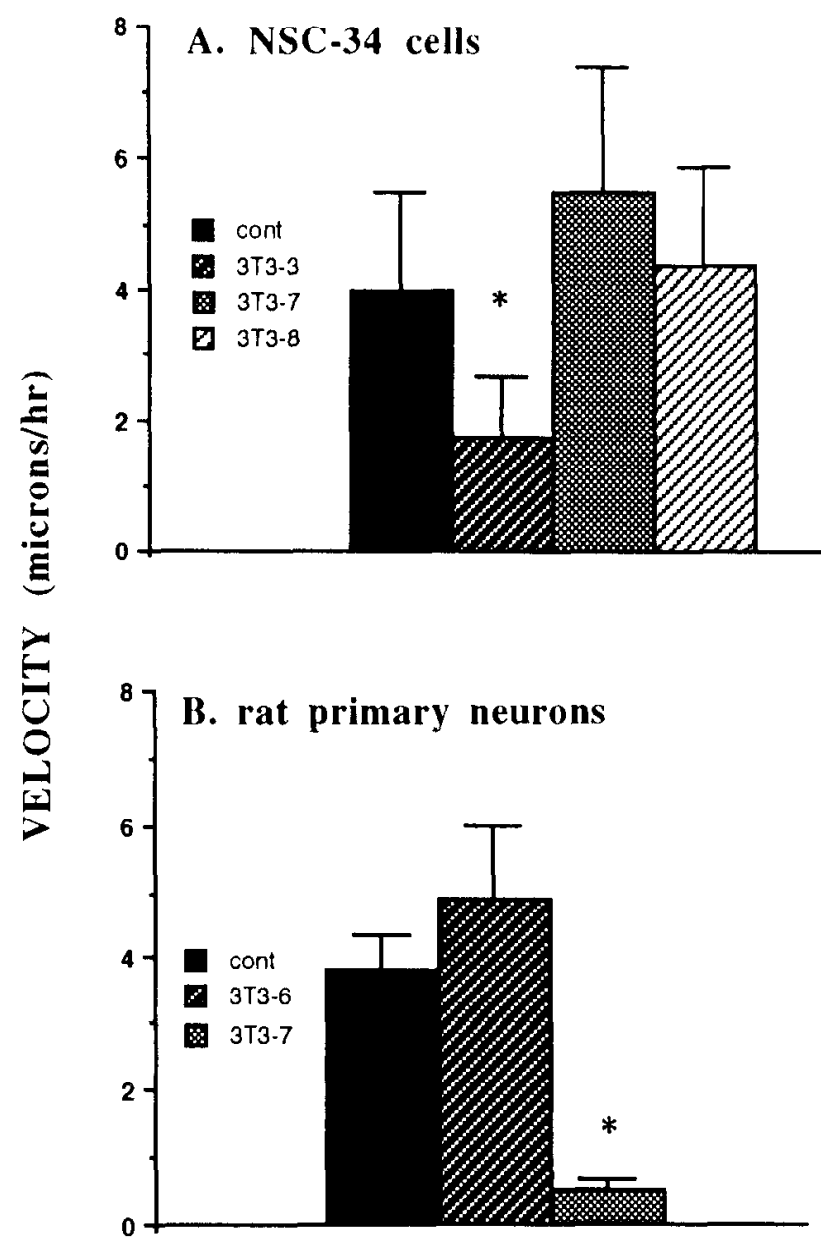

TREATMENT

Figure 6. Monoclonal anti-RHAMM antibody inhibition of neurite migration in cultures of NSC-34 cells and rat primary neurons. Cultures received additions of control mouse IgG (solid bar, cont) or the antiRHAMM antibodies indicated, and neurites were tracked for $1-2 \mathrm{hr}$ by image analysis. Antibodies 3T3-3 and 3T3-7 significantly inhibited neurite migration in NSC-34 and primary neurons, respectively. Error bars represent SD of between 20 and 30 neurites tracked.

vations, together with our detection of RHAMM in CNS neurons (unpublished observations), suggest that RHAMM is a major neuronal $\mathrm{HA}$ receptor and that it may mediate functions of IIA in the CNS.

Evidence for a causal link between RHAMM and neurite migration rests upon the ability of anti-RHAMM antibodies and HA binding domain peptides to alter migration. The sequence-specific polyclonal antibody A-268 found here to inhibit neurite extension was previously shown to reduce binding of HA to RHAMM and to block both random cell locomotion and chemotaxis (Hardwick et al., 1992; Savani et al., 1994a). It is plausible that since antibody A-268 inhibits HA/RHAMM interactions (Savani et al., 1994b), it blocks neurite extension by preventing interaction of HA with cell surface RHAMM. The cell-specific inhibition of neurite migration displayed by monoclonal anti-RHAMM antibodies raised against biochemically purified RHAMM is consistent with their similarly selective inhibitory actions on the motility of distinct $\mathrm{T}$ and $\mathrm{B}$ cell lineages, macrophages, and smooth muscle cells (Pilarski et al., 

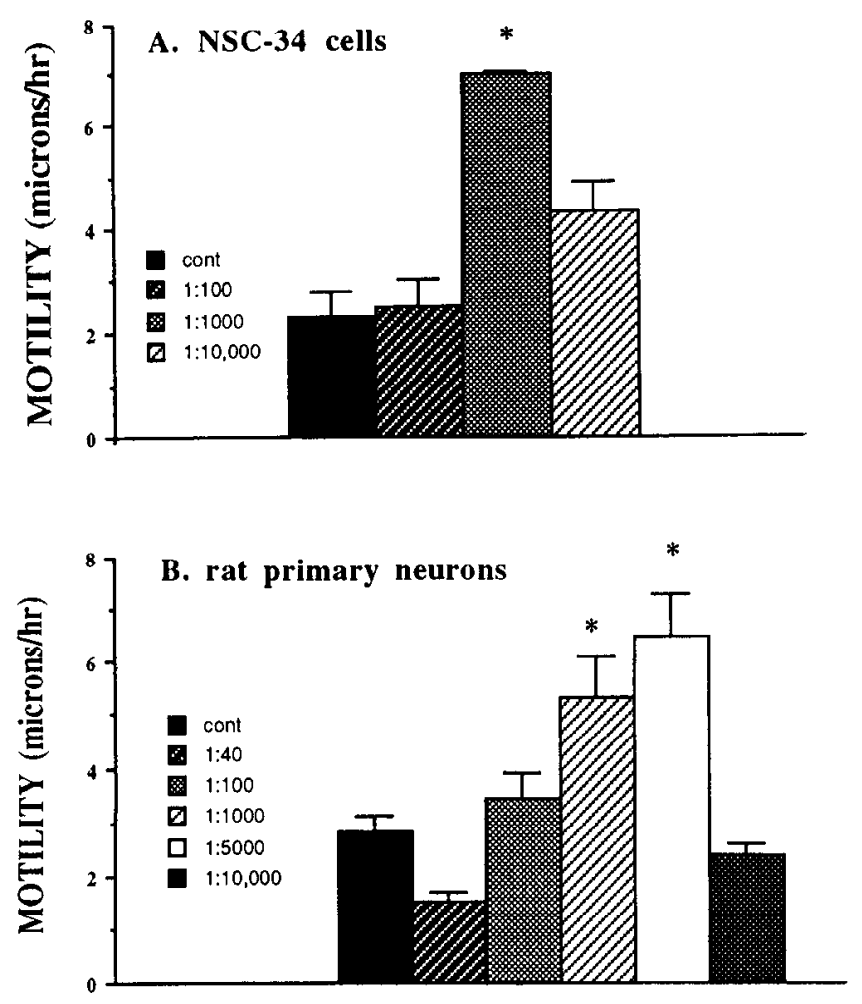

TREATMEN'T

Figure 7. Polyclonal anti-RHAMM antibody stimulation of neurite migration in cultures of NSC-34 cells and rat primary neurons. Cultures received additions of either control preimmune serum (solid bar, cont) or the indicated dilutions of an antibody against a repeat sequence domain in RHAMM, and neurites were tracked for 1-2 hr by image analysis. High concentrations of antibody (1:100 dilution) had no effect on neurite movement, while lower concentrations significantly $\left({ }^{*}, p<\right.$ 0.01 ) stimulated migration. Error bars represent SD of between 20 and 30 neurites tracked.

1993; Turley et al., 1993; Savani et al., 1994a). For example, some of these antibodies block fibroblast locomotion, but have no effect on thymocyte migration (Hardwick et al., 1992; Pilarski et al., 1993). It is possible that these antibodies recognize cellspecific glycosylation patterns of RHAMM or RHAMM sequences, peptide mapping of which is expected to provide a basis for antibody selectivity. The stimulatory antibody A-124, directed against a repeated sequence near the amino terminus of RHAMM (Hardwick et al., 1992) and found here to increase neurite migration, was recently reported to enhance fibroblast locomotion and to promote signal transduction events when added to cultures at low concentrations (Hall et al., 1994). Since repeated sequences are often sites of protein/protein interactions, it is possible that antibody A-124 may aid receptor crosslinking, which results in signaling and consequent motility (Hall et al., 1994). Stimulatory antibodies have also been reported for adhesion molecules on lymphocytes and the autocrine motility factor receptor $\mathrm{gp} 78$ where these promote adhesion, signaling events, and cell locomotion (Nabi et al., 1992). With respect to RHAMM peptides, those mimicking either of the two $\mathrm{HA}$ binding domains of this protein were shown to inhibit the TGF $\beta$-augmented locomotion of fibroblasts and to prevent chemotactic responses of macrophages (Samuel et al., 1993; Savani et al., 1994a). The HA binding capacity of these peptides is
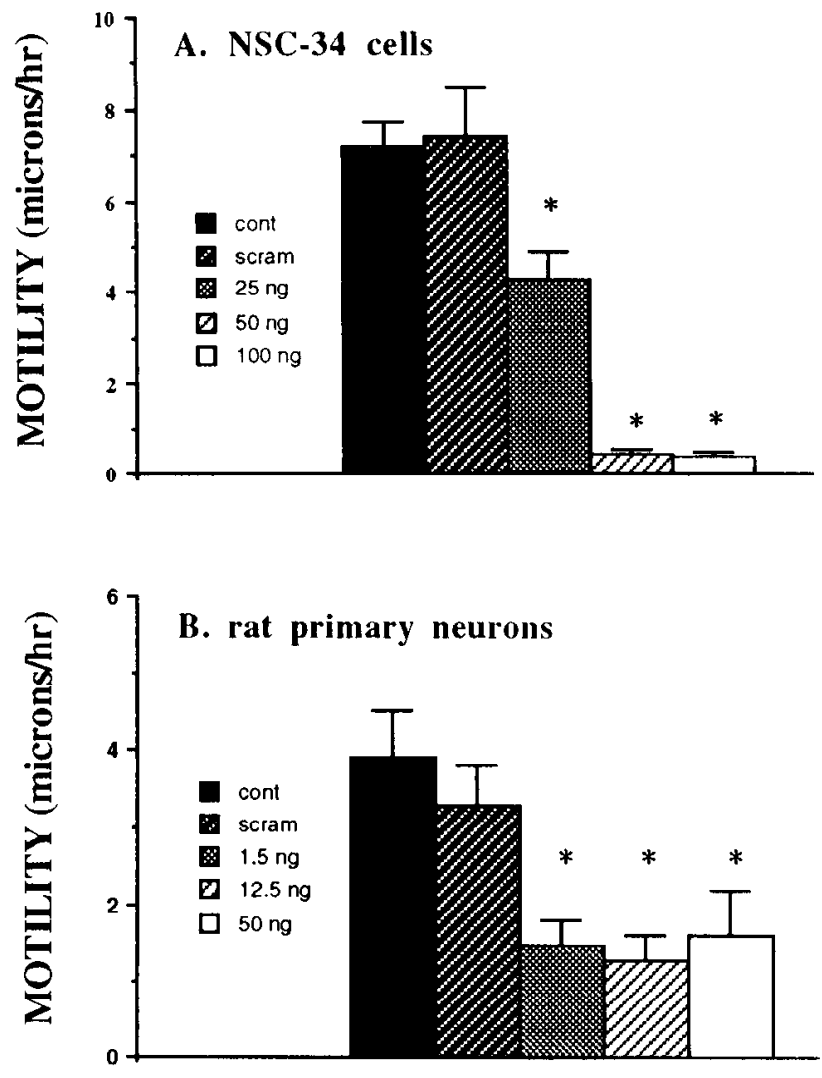

TREATMENT

Figure 8 . Inhibition of neurite migration by a peptide with amino acid sequence corresponding to one of the two HA binding domains of RHAMM. Cultures of NSC-34 cells and rat primary neurons were treated with either a buffer vehicle (cont), a scrambled version of the RHAMM peptide (scram), or various quantities ( $\mathrm{ng} / \mathrm{ml}$ of culture medium) of RHAMM peptide, and neurites were tracked for $1-2 \mathrm{hr}$ by image analysis. Scrambled peptide had no effect on neurite migration as compared with vehicle-treated controls. RHAMM peptide significantly inhibited $(*, p<0.01)$ neurite movement of both cell types at each of the three concentrations employed. Error bars represent SD of between 20 and 30 neurites tracked.

presumably key to their inhibition of neurite migration, since peptides with mutated HA binding motifs (Yang et al., 1993) no longer inhibit, for example, fibroblast locomotion.

Although neurites grow on substratum coated with HA combined with appropriate growth factors (Walicke, 1988), they are cither unaffected by, fail to grow, grow very poorly or actively avoid substratum coated with HA alone (Carbonetto et al., 1983; Saxod and Bizet, 1988; Verna et al., 1989). Similarly, peripheral cell types locomote poorly when plated on an HA substrate (Erikson and Turley, 1983; Tucker and Erikson, 1984). How can these already generally negative influences of HA on neurite extension be reconciled with the observed inhibition of this process following functional blockade of the HA receptor RHAMM? First, in view of the complex behavior displayed by cells and neurites grown on artificial ECM and cell adhesion factors (Reichardt et al., 1990; Bixby and Harris, 1991; Edelman, 1992), their behavior on a pure substrate, as in the case of $\mathrm{HA}$, cannot fully predict the functional contribution of that component to cell or neurite migration when present in an ECM composite. Second, concentrations, relative proportions, and pericellular distributions of ECM components are likely im- 
portant factors governing neurite migration. For example, the effect of HA on cell locomotion is concentration dependent and biphasic; motility is stimulated at low and inhibited at high concentrations (Bernanke and Markwald, 1979; Hakansson et al., 1980a,b; Hadden and Lewis, 1991; Turley et al., 1991) and a similar situation may hold for actions of HA on neurite migration. Third, the present studies were conducted with cells taken for analysis at specific times postplating. It remains to be determined whether RHAMM is equally involved in early rapid as well as sustained phases of neurite growth and migration (Smalheiser and Schwartz, 1987; Bixby and Jhabvala, 1990). And fourth, it would be premature to attribute antibody blockade of HA/RHAMM interactions as being singularly responsible for inhibition of neurite migration. Since HA binding domains are found in other ECM proteins including neurocan, versican/ GHAP, hyaluronectin, and aggrecan (Hardingham and Fosang, 1992; Laurent and Fraser, 1992; Rauch et al., 1992), it is conceivable that interference of HA binding to RHAMM alters HA interactions with other HA binding proteins. Conversely, RHAMM has been shown to bind to heparin, laminin, and collagen type IV, albeit with lower affinity than it binds to HA (Turley et al., 1987). Thus, anti-RHAMM antibodies and RHAMM peptides may affect neurite migration, in part, by interfering with interactions of RHAMM with other ECM components shown to affect neurite outgrowth (Carbonetto et al., 1983; Bozyczko and Horwitz, 1986; Carri et al., 1988; Dow et al., 1993). Finally, it should be noted that antibody blockade of RHAMM function only partially inhibits neurite motility. This less than total inhibition, also found previously with fibroblasts, may be due to RHAMM-independent mechanisms involving cell surface receptors such as integrins, CD44, and proteoglycans that contribute to a basal rate of cell locomotion.

The present results on the RHAMM/FCM system are similar to the intensely studied integrin class of ECM receptors and their ligands (Bixby and Harris, 1991; Neugebauer et al., 1991; Ruoslahti, 1992; Venstrom and Reichardt, 1993) in that the functional integrity of each is required for normal neurite migration. In addition, the RHAMM gene is complex encoding two isoforms as well as alternatively spliced entities that target the protein to the cell surface or to the extracellular compartment (Hardwick et al., 1992; Yang et al., 1994). This complexity is analogous to the multiple domain structure of such ECM proteins as fibronectin (Limper and Roman, 1992) and such cellspecific adhesion molecule as NCAMs (Wallis and Walsh, 1992). Interference with the function of these specific domains or receptor subunits impairs adhesion, growth, and other properties of neurites, depending on the moicty targeted (Carri ct al., 1988; Neugebauer et al., 1991; Doherty et al., 1992; Appel et al., 1993; Taylor et al., 1993). The present results are consistent with a similar existence of multiple RHAMM domains or isoforms that are differentially expressed and that may perform distinct cell-specific functions. Nevertheless, several differences are noteworthy. First, while anti-integrin antibodies differentially inhibit extension of neurites on the surface of some cell types as compared with ligand-coated substrata and, to some extent, cause previously extended neurites to detach and retract (Bozyczko and Horwitz, 1986; Tomaselli et al., 1987; Letourneau et al., 1988), anti-RHAMM antibodies inhibited equally well the migration of neurites on plastic and those dispersed on the surface of support cells, and only halt neurite movement rather than evoke their retraction. Second, unlike the $\mathrm{mm}$ concentrations of RGDS peptide required to interfere with integrin/fi- bronectin interactions (Letourneau et al., 1988; Lin et al., 1993), HA binding domain peptide of RHAMM had inhibitory actions in the nanomolar range. And third, while integrins appear to be concentrated mainly in neurites (Letourneau et al., 1988), RHAMM is distributed both in the cell bodies and neurites.

The molecular mechanisms underlying the contribution of RHAMM to neurite growth are not known. Immunoreactivity within ccll bodies and processes appeared to be localized largely to the plane of substrate attachment and consisted of distinct punctate deposits or patches, suggesting that RHAMM is targeted to discrete sites of cell/substrate interaction. Recently, we have reported that RHAMM regulates locomotion by a protein tyrosine phosphorylation cascade resulting in focal adhesion turnover and focal adhesion kinase (FAK) phosphorylation/ dephosphorylation (Hall et al., 1994). Although FAK is abundant in brain (Andre and Becker-Andre, 1993) and some reports have implicated a role of focal adhesions in growth cones (Halegoua, 1987; Igarashi et al., 1990; Cypher and Letourneau, 1991), these have not been well studied in the context of neurite extension. Since focal adhesions are well known to regulate fibroblast locomotion in vitro (Burridge et al., 1988) and given the above functional links between these structures and RHAMM, further studies may aim to determine whether a similar relationship exists between RHAMM and focal adhesions in neurites.

\section{References}

Akiyama H, Tooyama I, Kawamata T, Ikeda K, McGeer PL (1993) Morphological diversities of CD44 positive astrocytes in the cerebral cortcx of normal subjects and patients with Alzheimer's disease. Brain Res 632:249-259.

Andre E, Becker-Andre M (1993) Expression of an N-terminally truncated form of human focal adhesion kinase in brain. Biochem Biophys Res Commun 190:140-147.

Appel F, Holm J, Conscience J-F, Schachner M (1993) Several extracellular domains of the neural cell adhesion molecule $\mathrm{L} l$ are involved in neurite outgrowth and cell body adhesion. J Neurosci 13:47644775 .

Bernanke DH, Markwald RR (1979) Effects of hyaluronic acid on cardiac cushion tissue cells in collagen matrix cultures. Tex Rep Biol Med 39:271-285.

Bignami A, Asher R, Perides G (1991) Brain extracellular matrix and nerve regeneration. In: Advances in biological medicine: plasticity and regencration of the nervous system (Timiras PS, ed), pp 197206. New York: Plenum.

Bignami A, Hosley M, Dahl D (1993a) Hyaluronic acid and hyaluronic acid binding proteins in brain extracellular matrix. Anat Embryol (Berl) 188:419-433.

Bignami A, Perides G, Rahemtulla F (1993b) Versican, a hyaluronatebinding proteoglycan of embryonal precartilaginous mesenchyma, is mainly expressed postnatally in rat brain. J Neurosci Res 34:97-106.

Bixby JL, Harris WA (1991) Molecular mechanisms of axon growth and guidance. Annu Rev Cell Biol 7:117-159.

Bixby JL, Jhabvala P (1990) Extracellular matrix molecules and cell adhesion molecules induce neurites through different mechanisms. J Cell Biol 111:2725-2732.

Bozyczko D, Horwitz AF (1986) The participation of a putative cell surface receptor for laminin and fibroncetin in peripheral neurite extension. J Neurosci 6:1241-1251.

Burridge K, Fath K, Kelly T, Nuckolls G, Turner C (1988) Focal adhesions: transmembrane junctions between the extracellular matrix and the cytoskeleton. Annu Rev Cell Biol 4:487-525.

Carbonetto S, Gruver MM, Turner DC (1983) Nerve fiber growth in culture on fibronectin, collagen, and glycosaminoglycan substrates. J Neurosci 3:2324-2335.

Carri NG, Perris R, Johansson S, Ebendal T (1988) Differential outgrowth of retinal neurites on purified extracellular matrix molecules. J Neurosci 8:428-439. 
Cashman NR, Durham HD, Blusztajn JK, Oda K, Tabira T, Shaw IT, Dahrouge S, Antel JP (1992) Neuroblastoma $\times$ spinal cord (NSC) hybrid cell lines resemble developing motor neurons. Dev Dynam 194:209-221.

Cypher C, Letourneau PC (1991) Identification of cytoskeletal, focal adhesion, and cell adhesion proteins in growth cone particles isolated from developing chick brain. J Neurosci Res 30:259-265.

Delpech B, Delpech A, Bruchner G, Girard N, Maingonnat C (1989) Hyaluronan and hyaluronectin in the nervous system. In: Ciba Foundation symposium, Vol 143, The biology of hyaluronan (Evered D, Whelan J, eds), pp 208-232. Chichester: Wiley.

Devoto SH (1990) Neuronal growth cone migration. Experientia 46: 916-922.

Doherty P, Moolenaar CECK, Ashton SV, Michalides RJAM, Walsh FS (1992) The VASE exon downregulates the neurite growth-promoting activity of NCAM 140. Nature 356:791-793.

Dow KE, Guo M, Kisilevsky R, Riopelle RJ (1993) Regenerative neurite growth modulation associated with astrocyte proteoglycans. Brain Res Bull 30:461-467.

Edelman GM (1992) Mediation and inhibition of cell adhesion by morphoregulatory molecules. Cold Spring Harbor Symp Quant Biol 57:317-325.

Erikson CA, Turley EA (1983) Substrata formed by extracellular matrix combinations alter neural crest motility in vitro. J Cell Sci 61: 299-323.

Hadden CM, Lewis JH (1991) Hyaluronan as a propellant for epithelial movement: the development of semicircular canals in the inner ear of Xenopus. Development 112:541-550.

Hakansson L, Hallgren R, Venge P (1980a) Regulation of granulocyte function by hyaluronic acid. J Clin Invest 66:298-305.

Hakansson L, Hallgren R, Venge P, Artursson G, Vedung S (1980b) Hyaluronic acid stimulates neutrophil function in vitro and in vivo. Scand J Infect Dis [Suppl] 24:54-56.

Halegoua S (1987) Changes in the phosphorylation and distribution of vinculin during nerve growth factor induced neurite outgrowth. Dev Biol 121:97-104.

Hall CL, Wang C, Turley FA (1993) Hyaluronan/RHAMM interaction promotes tyrosine phosphorylation, focal adhesion turnover and cell locomotion in ras-transformed fibroblasts. Mol Biol Cell 4:1154.

Hall CL, Wang C, Lange LA, Turley EA (1994) Induction of focal adhesion turnover and transient tyrosine kinase activity in response to hyaluronan action on RHAMM. J Cell Biol, in press.

Hardinghan TE, Fosang AJ (1992) Proteoglycans: many forms and functions. FASEB J 6:861-870.

Hardwick C, Hohn HP, Hook M, Moore D, Cripps V, Austen L, Turley EA (1992) Molecular cloning of a novel hyaluronic receptor that mediates tumor cell motility. J Cell Biol 117:1343-1350.

Hunter DD, Cashman N, Morris-Valero R, Bulock JW, Adams SP, Sanes JR (1991) An LRE (leucine-arginine-glutamate)-dependent mechanism for adhesion of neurons to S-laminin. J Neurosci 11: 3960-3971.

Igarashi M, Saito S, Komiya Y (1990) Vinculin is one of the major endogenous substrates for intrinsic tyrosine kinases in neuronal growth cones isolated from fetal rat brain. Eur $\mathbf{J}$ Biochem 193:551-558.

Laurent TC, Fraser JRE (1992) Hyaluronan. FASEB J 6:2397-2404.

Letourneau PC, Pech IV, Rogers SL, Palm SL, McCarthy JB, Furcht LT (1988) Growth cone migration across extracellular matrix components depends on integrin, but migration across glioma cells does not. Neuroscience 21:286-297.

Limper AH, Koman J (1992) Fibronectin: a versatile matrix protein with roles in thoracic development, repair and infection. Chest 101: 1663-1673.

Lin WH, Higgins D, Pacheco M, Aletta J, Perini S, Marcucci KA, Roth JA (1993) Manganese induces spreading and process outgrowth in rat pheochromocytoma ( $\mathrm{PC1}$ 2) cells. I Neurosci Res 34:546-561.

Lipfert L, Haimovich B, Schaller MD, Cobb BS, Parsons JT, Brugge JS (1992) Integrin-dependent phosphorylation and activation of the protein tyrosine kinase pp125FAK in platelets. J Cell Biol 119:905912.

Margolis RU, Margolis RK (1989) Nervous tissue proteoglycans. Dev Neurosci 11:276-288.

Nabi IR, Watanabe H, Raz A (1992) Autocrine motility factor and its receptor: role in cell locomotion and metastasis. Cancer Met Rev $11: 5-20$.

Neugebauer KM, Emmett CJ, Venstrom KA, Reichardt LF (1991)
Vitroncctin and thrombospondin promote retinal neurite outgrowth: developmental regulation and role of integrins. Neuron 6:345-358.

Perides G, Erickson HP, Rahemtulla F, Bignami A (1993) Colocalization of tenascin with versican, a hyaluronate-binding chondroitin sulfate proteoglycan. Anat Embryol (Berl) 188:467-479.

Picker LJ, Nakache M, Butcher EC (1989) Monoclonal antibodies to human lymphocyte homing receptors define a novel class of adhesion molecules on diverse cell types. J Cell Biol 109:927-937.

Pilarski L, Miszta H, Turley EA (1993) Thymocyte development and expression of a novel HA receptor. J Immunol 150:4292-4302.

Rauch U, Karthikeyan L, Maurel P, Margolis RU, Margolis RK (1992) Cloning and primary structure of neurocan, a developmentally regulated, aggregating chondroitin sulfate proteoglycan of brain. J Biol Chem 267:19536-19547.

Reichardt LF, Tomaselli KJ (1991) Extraccllular matrix molcculcs and their receptors: functions in neural development. Annu Rev Neurosci 14:531-570.

Reichardt LF, Bossy B, Carbonetto S, De Curtis I, Emmett C, Hall DE, Ignatius MJ, Lefcort F, Napolitano E, Large T, Neugebauer KM, Tomaselli KJ (1990) Neuronal receptors that regulate axon growth Cold Spring Harbor Symp Quant Biol 55:341-350.

Ruoslahti E (1992) Control of cell motility and tumor invasion by extracellular matrix interactions. Br J Cancer 66:239-242.

Samuel SK, Hurta RAR, Spearman MA, Wright JA, Turley EA, Greenberg AH (1993) TGF- $\beta 1$ stimulation of cell locomotion utilizes the hyaluronan receptor RHAMM and hyaluronan. J Cell Biol 123:749_ 758.

Savani RC, Wang C, Khalil N, Stern R, Greenberg R, Turley EA (1993) Expression of hyaluronan and the hyaluronan receptor RHAMM following bleomycin lung injury. J Exp Med, in press.

Savani RC, Wang C, Shi Y, Kaplan C, Panek R, Stern R, Turley EA (1994a) Neointimal formation after balloon catheter injury: a role for hyaluronan and the hyaluronan receptor RHAMM. In press.

Savani RC, Wang C, Yang B, Kinsella M, Wight TN, Stern R, Turley EA (1994b) Molecular mechanisms of smooth muscle migration following wounding injury: the role of hyaluronan and RHAMM. In press.

Saxod R, Bizet M-C (1988) Substrate effects on the dynamics of neurite growth in vitro: a quantitative multi-parametric analysis. Int $\mathrm{J}$ Dev Neurosci 6:177-191.

Smalheiser NR, Schwartz NB (1987) Kinetic analysis of 'rapid onset' neurite formation in NG108-15 cells reveals a dual role for substratum-bound laminin. Dev Brain Rcs 34:111-121.

Stamenkovic I, Amiot M, Pesando JM, Seed B (1989) A lymphocyte molecule implicated in lymph node homing is a member of the cartilage link protein family. Cell 56:1057.

Taylor J, Pesheva P, Schachner M (1993) Influence of janusin and tenascin on growth cone behavior in vitro. J Neurosci 35:347-362.

Tomaselli KJ, Reichardt LF, Bixby JL (1987) Distinct molecular interactions mediate neuronal process outgrowth on non-neuronal cell surfaces and extracellular matrices. J Cell Biol 103:2659-2672.

Toole BP (1990) Biology of the hyaluradherins. Curr Opin Cell Biol 2:37-45.

Tucker RP, Erickson CA (1984) Morphology and behavior of quail neural crest cells in artificial three-dimensional extracellular matrices. Dev Biol 104:390-405.

Turley EA (1991) Hyaluronan binding proteins and Receptors. Adv Drug Deliv Rev 7:257-264.

Turley EA (1992) Hyaluronan mediated cell locomotion. Cancer Metastasis Rev 11:21-30.

Turley EA, Torrance J (1985) Localization of hyaluronate and hyaluronate binding protein on motile and non motilc fibroblasts. Exp Cell Res 161:17-28.

Turley EA, Moore D, Hayden LJ (1987) Characterization of hyaluronate binding proteins isolated from 313 and murine sarcoma virus transformed 3T3 cells. Biochem 26:2997-3005.

Turley EA, Austen L, Vandeligt K. Clary C (1991) Hyaluronan and cell associated hyaluronan binding protein regulate the locomotion of ras transformed cells. J Cell Biol 112:1041-1047.

Turley EA, Belech A, Pilarski L (1993) Expression of RHAMM on normal and malignant $B$ cells. Blood 81:446-453.

Turley EA, Hossain MZ, Sorokan T, Jordan LM, Nagy JI (1994) Astrocyte and microglial motility in vitro is functionally dependent on the hyaluronan receptor RHAMM. In press. 
Valnes K, Brandtzaeg P (1985) Retardation of immunofluorescence fading during microscopy. J Histochem Cytochem 33:755-761.

Venstrom KA, Reichardt LF (1993) Extracellular matrix 2: role of extracellular matrix molecules and their receptors in the nervous system. FASEB J 7:996-1003.

Verna J-M, Fichard A, Saxod R (1989) Influence of glycosaminoglycans on neurite morphology and outgrowth patterns in vitro. Int $\mathrm{J}$ Dev Neurosci 7:389-399.

Walicke PA (1988) Interactions between basic fibroblast growth factor (FGF) and glycosaminoglycans in promoting neurite outgrowth. Exp Neurol 102:144-148.

Wallis J, Walsh FS (1992) Structure of the genes encoding the neural cell adhesion molecules N-CAM and N-cadherin. Biochem Soc Trans 20:656-658

Werz W, Fischer G, Schachncr M (1985) Glycosaminoglycans of rat cerebellum: I. Quantitative analysis of the main constituents at postnatal day 6. J Neurochem 44:900-906.

Yang B, Zhang L, Turley EA (1993) Identification of hyaluronan binding motifs in a novel hyaluronan receptor RHAMM. J Biol Chem 268:8617-8623.

Yang B, Enwistle J, Wang C, Zhang S, Yang BL, Mowat M, Greenberg $\mathrm{AH}$, Turley EA (1994) Cloning and analysis of a complete gene encoding a hyaluronan receptor RHAMM. Mol Biol Cell 4:1111. 